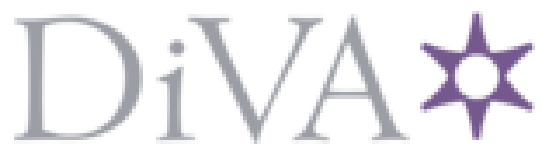

http://www.diva-portal.org

This is the published version of a paper published in Criminal Justice Review.

Citation for the original published paper (version of record):

Ceccato, V. (2021)

Special Issue-Contemporary Issues in Brazilian Criminology

Criminal Justice Review

https://doi.org/10.1177/07340168211038260

Access to the published version may require subscription.

N.B. When citing this work, cite the original published paper.

Permanent link to this version:

http://urn.kb.se/resolve?urn=urn:nbn:se:kth:diva-301963 


\title{
Special Issue-Contemporary Issues in Brazilian Criminology
}

Criminal Justice Review

I-4

(C) 2021 Georgia State University

\section{Vania Ceccato' ${ }^{\prime}$}

\begin{abstract}
This special issue features seven articles among those presented at the workshop "Crime and Perceived Safety in Brazil" (Crime e Percepção de Segurança in Brazil) in Campinas, Brazil, in December 2019. The special issue reflects an array of themes of contemporary criminology in Brazil, from homicides and corruption to fear of crime and crime prevention. This special issue reflects the interdisciplinary character of the workshop with participating researchers from several Brazilian universities. For a selection of other articles from this workshop, see the second special issue to be published in the Journal of Contemporary Criminal Justice in 2022.
\end{abstract}

\section{Keywords}

crime, safety, Brazil, Global South, multidisciplinary

\section{Sumário}

Esta edição especial apresenta um conjunto de sete artigos apresentados no workshop "Crime e Percepção de Segurança no Brasil” (Crime and Perceived Safety in Brazil) em Campinas, Brasil em Dezembro de 2019. A edição especial reflete uma variedade de temas da criminologia contemporânea do Brasil, que vai desde temas como homicídios, corrupção até o medo e prevenção do crime. Esta edição especial reflete o caráter interdisciplinar do encontro com a participação de pesquisadores de várias universidades brasileiras. Note que uma outra seleção de artigos deste workshop será publicado no Journal Contemporary Criminal Justice em 2022.

\section{Palavras-chave}

Crime, segurança, Brasil, Sul Global, multidisciplinar

\section{Why a Special Issue on Brazilian Criminology?}

Brazil constitutes an interesting international case study. The country has continental dimensions and is the most populous country in Latin America (and the sixth most populous globally) with 214 million inhabitants in 2021 (Worldometer, 2021). The country comprises one federal district, 26 states, and 5,570 municipalities. Violence has historically featured in the country's colonization by

\footnotetext{
' Department of Urban Planning and Environment, Royal Institute of Technology (KTH), Stockholm, Sweden

Corresponding Author:

Vania Ceccato, Department of Urban Planning and Environment, Royal Institute of Technology (KTH), Teknikringen I0A, Stockholm 100 44, Sweden.

Email: vania.ceccato@abe.kth.se
} 
forced occupation and slavery (Langfur, 2006), and currently, the country is one of the most criminogenic in the world (UNODC, 2018); especially vulnerable are women and LGBTIQ Lesbian, Gay, Bisexual, Transgender, Intersex and Questioning people (Economic Commission for Latin America and the Caribbean, 2019; Mendes \& Silva, 2020). The country has also one of the most violent police forces in the world (Forum Brasileiro de Seguranca Publica [FBSP], 2016) as well as hundreds of deaths each year in land conflicts (Ceccato \& Ceccato, 2017), reflecting the legacy of a society with extreme infringements of basic human rights. Therefore, the systematic review of the literature presented by Ceccato, Kahn, and Vazquez contributes to the field by exploring these issues and reporting the nature, trends, determinants, and impact of lethal violence on society, as well as interventions to combat them from 2000 to 2020 . They show that high homicide rates constitute a chronic problem in Brazil (Murray et al., 2013), a country where violence is exacerbated by socioeconomic inequalities, racism (Instituto de Pesquisa Econômica Aplicada/ FBSP, 2016), and many social problems, including corruption.

Even though Brazil is just below the regional average of perceived corruption in Latin America and the Caribbean in 2020, with a score of 38 out of 100 , the country has steadily maintained a position among the more corrupt countries in the world (94th out of 180 countries, 1 is the least corrupt country; Transparency International, 2021). The article by Saad-Diniz exams corporate complicity with authoritarian regimes of the past and contemporary practices in Brazil, exemplifying ways in which business interacted with authoritarian regimes as well as determined processes of victimization and human rights violations. The author also shows striking coincidences between the corporate network that financed the military dictatorship and the more recent actors involved in Operation Car Wash, the largest corruption investigation in the country's history.

The other side of the same coin is the problem of tax evasion that is also very high in Brazil (Clemente \& Lírio, 2018), a problem for society in general that reduces the public budget which could be allocated to the provision of vital services such health, education, and safety. But Brazil is not the only one, as Clemente and Lírio show that tax evasion is directly associated with tax burden and audit cost in other countries. Their study investigates the differences observed in the rates of tax evasion between countries of the Global North and South, with a special focus on Brazil. Authors found a number of shortcomings in the tax system of Latin American economies that create the avenue for high tax evasion, which can only be resolved or reduced through auditing rather than reforming the entire tax system. They suggest that tax evasion can be reduced if the tax burden and audit costs were lower.

These facts alone can inspire researchers from all around the world to engage in research devoted to crime and public security challenges in Brazil and the Global South, partially because some problems may share a number of commonalities. Being male, young, Black, with little schooling, living in a place with great social inequality (such as urban peripheries and agricultural frontiers, added to a lack of work and income) and being involved with trafficking/drugs stand out as determinants of homicide in contemporary Brazil (Wanzinack, 2018). However, not all become criminals, and crucial choices made along one's life path determine one's destiny (based on a decision to commit a crime) and potentially becoming part of the crime statistics. Bauermann, Shikida, and Schlemper investigate young people's choices between the legal and illegal economic sectors. They studied responses from a survey of young people aged 18-23 years, accused of economic crimes, convicted or detained in prison units in two states of Brazil (Paraná and Rio Grande do Sul) to conclude that those choosing crime demonstrate, among other things, family and educational issues and lack of trust in public authorities. The authors suggest that attention should be paid to the strengthening of moral barriers related to the interaction between family and school, for example; at the same time that it is necessary to expand the costs of illegal activity, and decreasing the benefits resulting from involvement in illegal markets.

In the same vein of research, the study carried out by Dantas and Favarin shows the existence of a spatial association between violence and urban vulnerabilities in Fortaleza in the Brazilian state of 
Ceará, Brazil. This evidence raises numerous possibilities in terms of crime prevention strategies and predictive policing in Fortaleza, and Latin America. More interestingly, the authors suggest the use of a targeted strategy that would combine a wide range of public policies in problematic areas. These areas in particular should, according to authors, constitute the primary target of public policies designed to reduce vulnerabilities and enhance socio-economic conditions, in conjunction with the implementation of both preventive policing and long-term community-based policing measures.

Programs of crime prevention are not always effective, and there exist several factors that help explain why public policy works or not. This issue is addressed in the study by Castro, Justus, and Kassouf, who evaluate the impact of a national public security program on the homicide rates in Brazil. Using municipalities as the unit of analysis, the authors find that the program was inefficient in reducing the homicide rate in all of the municipalities. Although expected, results indicate potential explanations for why the program failed, in particular its complexity, poor management, and lack of long-term monitoring.

Individuals' lack of trust in public authorities in general, and in the police in particular, has a major impact on society. Fear is one of them. Truzzi, Justus, Kawamura, and Conti estimate the relationship between perceived violence and private spending on household security. They find that the perception of violence in the area of residence (subjective risk of victimization), the neighbors' security spending (spillover effect of the neighbor's decision), and the recorded rates of crime against people and property positively affect a household's private spending on security. More interestingly, findings are also indicative of people's dissatisfaction with the police and public security services. The authors conclude that in a country with major socioeconomic inequalities, because private security is a privilege for some only, reducing fear of crime should be one of the priorities of public security policies in Brazil.

Despite its relevance, much of this scholarship is unknown to most of the international research community, as most articles written in Portuguese are not widely accessible (despite it being the ninth most common language in the world and the second most common Roman language, after Spanish; (Meneghini \& Packer, 2007). We are delighted that this special issue has promoted collaborative frameworks of research beyond Brazilian borders.

Another feature of this special issue is that it includes multidisciplinary contributions from the fields of criminology, economics, geography, public policy, and other related fields. Similarly, methods employed in the special issue vary from highly quantified pieces (with modeling, Geographical Information Systems, and spatial statistics) to qualitative studies (based on survey data and text analysis) and mixed methods approaches.

\section{Acknowledgments}

I am grateful to all the authors who contributed to this special issue. I would like to thank Josh Hinkle and the Criminal Justice Review for welcoming the idea of this special issue. I also thank my editorial team in Stockholm and the anonymous referees for sharing their knowledge through their comments and suggestions: Cody Telep, Richard Block, David Kennedy, Lars Korsell, Nubia Evertsson, Ingrid Hoem Sjursen, Mats Wilhelmsson, Marcelo Justus, Fredrik Kopsch, David Whyte, Gregg Barak, John Braithwaite, Robert Haining, Framklin Almeida, Brendon McConell, Melissa Thompson, Karen Gueta, Linda Montanari, and unknown referees via Marcelo Justus. I am grateful to Marcelo Justus, Temidayo James Aransiola, and Bruno Truzzi for organizing the workshop "Crime e Percepção de Segurança in Brazil" (Crime and Perceived Safety in Brazil), on December 4-5, 2019, at the Institute of Economics, University of Campinas (Unicamp) which culminated in this special issue and the creation of a new arena of discussion (which translates to "Criminology and Economics") that is currently active and appreciated by scholars. Thanks also to the São Paulo Research Foundation (FAPESP) for funding the workshop and for the indirect support of KTH Safeplaces network. 


\section{Declaration of Conflicting Interests}

The author declared no potential conflicts of interest with respect to the research, authorship, and/or publication of this article.

\section{Funding}

The author received no financial support for the research, authorship, and/or publication of this article.

\section{ORCID iD}

Vania Ceccato (D) https://orcid.org/0000-0001-5302-1698

\section{References}

Ceccato, V., \& Ceccato, H. (2017). Violence in the rural global south: Trends, patterns, and tales from the Brazilian Countryside. Criminal Justice Review, 42(3), 270-290. https://doi.org/10.1177/073 4016817724504

Clemente, F., \& Lírio, V. S. (2018). Tax evasion in Brazil: The case of specialists. Journal of Economic Studies, 45(2), 401-410. https://doi.org/10.1108/JES-11-2016-0247

Economic Commission for Latin America and the Caribbean. (2019). Femicide or feminicide. Gender equality observatory for Latin America and the Caribbean. https://oig.cepal.org/en/indicators/femicide-orfeminicide

Fórum Brasileiro de Segurança Pública (FBSP). (2016). Anuário Brasileiro de Segurança Pública. http:// www.forumseguranca.org.br/atividades/anuario/

Instituto de Pesquisa Econômica Aplicada/Forum Brasileiro de Seguranca Publica. (2016). Atlas da Violência 2016. Nota Tecnica.

Langfur, H. (2006). The forbidden lands: Colonial identity, frontier violence, and the persistence of Brazil's Eastern Indians. Stanford University Press.

Mendes, W. G., \& Silva, M. F. P. (2020). Homicide of lesbians, gays, bisexuals, travestis, transexuals, and transgender people (LGBT) in Brazil: A spatial analysis. Ciência da Saúde Coletiva, 25. https://doi.org/ 10.1590/1413-81232020255.33672019

Meneghini, R., \& Packer, A. L. (2007). Is there science beyond English? EMBO Reports, 8(2), 112-116. https:// doi.org/https://doi.org/10.1038/sj.embor.7400906

Murray, J., Cerqueira, D. R. d. C., \& Kahn, T. (2013). Crime and violence in Brazil: Systematic review of time trends, prevalence rates and risk factors. Aggression and Violent Behavior, 18(5), 471-483. https://doi.org/ https://doi.org/10.1016/j.avb.2013.07.003

Transparency international. (2021). Corrupcions perception index. https://www.transparency.org/en/

UNODC - United Nations Office on Drugs and Crime. (2018). Global study on homicide 2018 (Vienna, 2018).

Wanzinack, C. (2018). Violencia, territorio e desenvolvimento: Uma proposta de analise dos homicidios do Brasil baseada nos determinantes socioambientais da saude, Blumenau (Violence, territory and development: A proposal to assess homicides based on socio-environmental determinants of health in Blumenau, Brazil), [Doctoral dissertation]. http://www.bc.furb.br/docs/TE/2018/366433_1_1.pdf

Worldometer. (2021). Brazil population. https://www.worldometers.info/world-population/brazil-population/

\section{Author biography}

Vania Ceccato is a Professor in the Department of Urban Planning and Environment, KTH Royal Institute of Technology, Stockholm Sweden. Her research is international in scope and has mostly focused on the situational conditions of crime and fear in urban and rural environments from an interdisciplinary perspective. Ceccato is the national coordinator of Safeplaces network, a partner of UN-Habitat SaferCities program. 